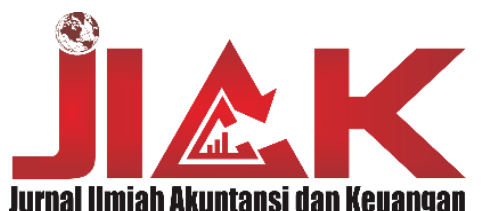

http://journal.stieputrabangsa.ac.id/index.php/jiak

ISSN: 2580-510X/ P-ISSN: 2548-9453

ARTICLE INFORMATION

Received June $19^{\text {th }} 2020$

Accepted January $30^{\text {th }} 2021$

Published January $31^{\text {st }} 2021$

DOI:

https://doi.org/10.32639/jiak. v9i2.599

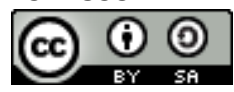

\section{Perlakuan Akuntansi Belanja Tak Terduga pada Pemerintah Daerah Akibat Pandemi Covid-19}

\author{
Dani Sugiri \\ Politeknik Keuangan Negara STAN \\ email: danisugiri@pknstan.ac.id
}

\begin{abstract}
ABSTRAK
Dalam keadaan darurat pandemi COVID-19 pemerintah daerah dapat memberikan melakukan belanja dengan menggunakan Belanja Tak Terduga dalam Anggaran Pendapatan dan Belanja Daerah (APBD) yang pada kondisi normal jarang dilakukan. Penelitian ini bertujuan untuk menjelaskan perlakukan akuntansi Belanja Tak Terduga oleh pemerintah daerah yang meliputi pengakuan, pengukuran dan penyajian dalam laporan keuangan. Penelitian dilakukan dengan menggunakan studi literatur untuk mengetahui bagaimana perlakuan akuntansi untuk belanja tak terduga pada pemerintah daerah. Hasil penelitian dapat digunakan sebagai acuan oleh pemerintah daerah dalam memperlakukan belanja tak terduga yang telah direalisasikan selama masa pandemi COVID-19.
\end{abstract}

Kata kunci: Belanja tak Terduga; Pengakuan; Pengukuran; Penyajian; Akuntansi Pemerintah Daerah

\begin{abstract}
In an emergency pandemic COVID-19 the local government can provide spending using Unexpected Expenditures in the Regional Revenue and Expenditure Budget (APBD) which under normal conditions is rarely done. This study aims to explain the accounting treatment of Unexpected Expenses by local governments which includes recognition, measurement and presentation in financial statements. The study was conducted using literature studies to find out how accounting treatment for unexpected expenditure on local government. The results of the study can be used as a reference by local governments in treating unexpected expenditures that have been realized during the COVID-19 pandemic.
\end{abstract}

Keywords: Unexpected Expenditure; Recognition; Measurement; Presentation; Local Government Accounting

\title{
PENDAHULUAN
}

Pandemi COVID-19 telah memberikan dampak ke berbagai sektor dalam kehidupan masyarakat, termasuk sektor keuangan daerah. Pemerintah daerah sebagai penyelenggara pemerintahan dalam era desentralisasi saat ini, memiliki peran strategis dalam mengatasi pandemi COVID-19. Namun umumnya 
pemerintah daerah menghadapi situasi yang cukup sulit. Pada sisi belanja, pemerintah daerah harus menghadapai kenyataan bahwa kebutuhan belanja makin meningkat, terutama untuk kegiatan mengatasi pandemi COVID-19. Sebagai suatu wabah, sudah barang tentu berbagai kegiatan atau program penanggulanganannya belum sepenuhnya teralokasi dalam Anggaran Pendapatan dan Belanja Daerah (APBD). Pada sisi pendapatan, lesunya perekonomian berefek pada menurunnya pendapatan pemerintah daerah. Oleh karena itu, pengelolaan keuangan daerah perlu dilakukan secara hati-hati agar tercapai tujuan program dan kegiatan tanpa meninggalkan tertib dan disiplin anggaran.

Presiden melalui instruksi Nomor 4 Tahun 2020 menyatakan bahwa dengan penetapan wabah COVID-19 sebagai pandemi global, maka seluruh jajaran pemerintahan harus melakukan refocussing kegiatan, realokasi angagran serta pengadaan barang dan jasa dalam rangka percepatan penanganan COVID19. Menteri Dalam Negeri dan Menteri Keuangan telah menyepakati keputusan bersama No. 119/2813/SJ dan No. 177/KMK.07/2020 yang mengatur mengenai keharusan seluruh Pemda melakukan penyesuaian APBD TA 2020 dengan (a) melakukan penyesuaian (penurunan) target pendapatan dalam APBD; (b) melakukan penyesuaian belanja daerah melalui rasionalisasi belanja pegawai, barang, dan belanja modal, dan (c) refocusing dan realokasi belanja untuk pembiayaan kegiatan dalam rangka percepatan penanganan covid-19. Kegiatan dalam rangka percepatan penanganan COVID-19 dapat berupa belanja bidang kesehatan, penyediaan jariangan pengaman sosial, dan penanganan dampak ekonomi.

Belanja Tak Terduga merupakan jenis belanja yang jarang digunakan dalam suatu Anggaran Pendapatan dan Belanja Daerah (APBD). Dalam masa pandemi COVID-19, anggaran belanja Tak Terduga menjadi hal yang menarik dibicarakan karena alokasi anggaran ini saat ini banyak digunakan untuk membiaya kegiatan penanganan COVID-19. Kegiatan penanganan COVID-19 tersebut dapat merupakan kegiatan pengadaan bahan kesehatan, alat kesehatan, dan bahkan

Permasalahan yang diangkat dalam penelitian ini adalah bagaimana perlakukan akuntansi atas belanja tak terduga yang dilakukan oleh Pemerintah Daerah. Perlakuan akuntansi tersebut meliputi pengakuan, pengukuran dan penyajian dalam laporan keuangan. Selain itu, penelitian ini menyajikan contoh transaksi pada Satuan Kerja Perangkat Daerah (SKPD) atau Organisasi Perangkat Daerah (OPD) suatu Pemerintah Daerah.

Penelitian ini bertujuan untuk mengetahui bagaimana perlakuan akuntansi bagi belanja tak terduga yang sesuai dengan standar, kebijakan dan sistem akuntansi yang berlaku saat ini di pemerintah daerah. Hasil penelitian ini diharapkan dapat bermanfaat bagi pemerintah daerah dan para pemerhati keuangan daerah untuk memahami perlakukan akuntansi untuk belanja tak terduga yang sedang banyak disorot saat ini.

\section{KAJIAN LITERATUR}

\section{Basis Akuntansi dan Laporan Keuangan yang Dihasilkan}

Medina (2014) menyebutkan bahwa walaupun SAP menurut PPP Nomor 71 Tahun 2010 menganut konsep berbasis akrual, namun pencatatan dan penyajian dalam basis kas masih dibutuhkan. Dalam Kerangka Konseptual paragraph 44 disebutkan bahwa dalam hal anggaran disusun dan dilaksanakan berbasis kas, maka LRA disusun berdasarkan basis kas. Sampai dengan saat ini, pemerintah daerah masih menggunakan anggaran dengan basis kas (Medina, 2014), sehingga pengakuan dengan basis kas masih diperlukan. Dengan berjalannya pendekatan akrual yang bersamaan dengan pendekatan kas, laporan keuangan pemerintah daerah dapat tersaji secara lengkap. Standar Akuntansi Pemerintah (SAP) Berbasis Akrual menghendaki laporan keuangan pemerintah daerah terdiri atas Neraca, Laporan Realisasi Anggaran (LRA), Laporan Operasional (LO), Laporan Arus Kas (LAK), Laporan Perubahan Ekuitas (LPE), Laporan Perubahan SAL (LP-SAL), serta Catatan atas Laporan Keuangan (CaLK). 


\section{Sistem Akuntansi Pemerintah Daerah dan Kontruksi}

Mulyana (2014) menyebutkan bahwa sistem akuntansi keuangan pemerintah daerah tersusun atas dua sistem. Pertama, Sistem Akuntansi Pelaksanaan Anggaran (SAPA) dengan pendekatan berbasis kas. SAPA juga sering disebut secara populer dengan jurnal kas. Kedua, Sistem Akuntansi Keuangan (SAK) dengan pendekatan berbasis akrual. SAK juga sering disebut sebagai jurnal akrual. Kedua subsistem tersebut dijalankan oleh pihak Pengguna Anggaran dan oleh Bendahara Umum Daerah (BUD). Pengguna Anggaran diperankan oleh Satuan Kerja Perangkat Daerah (SKPD) atau Organisasi Perangkat daerah (OPD). Sedangkan BUD diperankan oleh Pejabat Pengelola Keuangan Daerah sebagaimana diatur dalam PP Nomor 12 Tahun 2019. Suatu transaksi dalam suatu pemerintah daerah akan dianalisis dan dicatat dengan mempergunakan jurnal kas dan/atau jurnal akrual baik pada SKPD/OPD dan/atau PPKD (DJPK, 2016).

\section{Definisi Belanja Tak Terduga}

Dalam Pernyataan Standar Akuntansi Pemerintah (PSAP) No 2 paragraf 34 disebutkan bahwa belanja pemerintah diklasifikasikan menurut klasifikasi ekonomi (jenis belanja), organisasi, dan fungsi. Klasifikasi ekonomi adalah pengelompokan belanja yang didasarkan pada jenis belanja untuk melaksanakan suatu aktivitas. Klasifikasi ekonomi untuk pemerintah daerah meliputi belanja pegawai, belanja barang, belanja modal, bunga, subsidi, hibah, bantuan sosial, dan belanja tak terduga (PSAP 02 Paragraf 35).

DJPK (2020) mendefinisikan Belanja Tak Terduga sebagai pengeluaran anggaran untuk kegiatan yang sifatnya tidak biasa dan tidak diharapkan berulang seperti penanggulangan bencana alam, bencana sosial, dan pengeluaran tidak terduga lainnya yang sangat diperlukan dalam rangka penyelenggaraan kewenangan pemerintah pusat/daerah. PSAP Nomor 02 paragraf 38 juga memberikan definisi yang sama tentang Belanja Tak Terduga.

Dalam Buletin Teknis Nomor 4 disebutkan bahwa realisasi belanja tak terduga dicatat dan disajikan pada LRA sebagai Belanja Tak Terduga. Jika dari hasil pengeluaran belanja tak terduga diperoleh aset tetap, maka aset tetap tersebut dicatat dan disajikan di neraca Pemda.

Klasifikasi Belanja Daerah terdiri atas belanja operasi, belanja modal, belanja tidak terduga, dan belanja transfer (PP 12 Tahun 2019 Pasal 55 ayat 1 s.d. 5).

a. Belanja operasi sebagaimana dimaksud pada ayat (1) huruf a merupakan pengeluaran anggaran untuk Kegiatan sehari-hari Pemerintah Daerah yang memberi manfaat jangka pendek.

b. Belanja modal sebagaimana dimaksud pada ayat (1) huruf b merupakan pengeluaran anggaran untuk perolehan aset tetap dan aset lainnya yang memberi manfaat lebih dari 1 (satu) periode akuntansi.

c. Belanja tidak terduga sebagaimana dimaksud pada ayat (1) huruf c merupakan pengeluaran anggaran atas Beban APBD untuk keperluan darurat termasuk keperluan mendesak yang tidak dapat diprediksi sebelumnya.

d. (5) Belanja transfer sebagaimana dimaksud pada ayat (1) huruf d merupakan pengeluaran uang dari Pemerintah Daerah kepada Pemerintah Daerah lainnya dan/atau dari Pemerintah Daerah kepada pemerintah desa.

Belanja Tak Terduga digunakan untuk mencatat penurunan manfaat ekonomi atau potensi jasa dalam periode pelaporan yang menurunkan ekuitas dalam bentuk pengeluaran berupa beban tak terduga (Permendagri No. 90 Tahun 2019 Lampiran).

Dalam PP Nomor 12 Tahun 2019 Pasal 56 dijelaskan bahwa Belanja operasi dirinci menjadi jenis belanja pegawai; belanja barang dan jasa; belanja bunga; belanja subsidi; belanja hibah; dan belanja bantuan sosial.

PP Nomor 12 Tahun 2019 Pasal 68 menyebutkan bahwa belanja tidak terduga merupakan pengeluaran anggaran atas Beban APBD untuk keadaan darurat termasuk keperluan mendesak serta pengembalian 
atas kelebihan pembayaran atas Penerimaan Daerah tahun-tahun sebelumnya. Selanjutnya dalam PP 12 Tahun 2019 Pasal 69 ayat 1 dijelaskan bahwa keadaan darurat yang perlu dibiayai dengan Belanja Tak Terduga meliputi:

a. bencana alam, bencana non-alam, bencana sosial dan/atau kejadian luar biasa;

b. pelaksanaan operasi pencarian dan pertolongan; dan/atau

c. kerusakan sarana/prasarana yang dapat mengganggu kegiatan pelayanan publik.

Dalam PP 12 Tahun 2019 Pasal 69 ayat 2, diatur bahwa suatu kondisi atau keperluan mendesak meliputi:

a. kebutuhan daerah dalam rangka Pelayanan Dasar masyarakat yang anggaranya belum tersedia dalam tahun anggaran berjalan;

b. Belanja Daerah yang bersifat mengikat dan belanja yang bersifat wajib;

c. Pengeluaran Daerah yang berada di luar kendali Pemerintah Daerah dan tidak dapat diprediksikan sebelumnya, serta amanat peraturan perundang-undangan; dan/atau

d. Pengeluaran Daerah lainnya yang apabila ditunda akan menimbulkan kerugian yang lebih besar bagi Pemerintah Daerah danl atau masyarakat.

Kriteria keadaan darurat dan keperluan mendesak dalam PP 12 Tahun 2019 Pasal 69 ayat 1 dan ayat 2 ditetapkan dalam Perda tentang APBD tahun berkenaan.

(4) Pengeluaran untuk mendanai keadaan darurat yang belum tersedia anggarannya, diformulasikan terlebih dahulu dalam RKA SKPD, kecuali untuk kebutuhan tanggap darurat bencana, konflik sosial, dan/atau kejadian luar biasa.

(5) Belanja untuk kebutuhan tanggap darurat bencana, konflik sosial, dan/atau kejadian luar biasa sebagaimana

dimaksud pada ayat (4) digunakan sesuai dengan ketentuan peraturan perundang-undangan.

(6) Pengeluaran untuk mendanai keperluan mendesak yang belum tersedia anggarannya dan/atau tidak cukup tersedia anggarannya, diformulasikan terlebih dahulu dalam RKA SKPD dan/atau Perubahan DPA SKPD.

Beban diklasifikasikan menurut klasifikasi ekonomi. Klasifikasi ekonomi pada prinsipnya mengelompokkan berdasarkan jenis beban. Klasifikasi ekonomi untuk pemerintah pusat yaitu beban pegawai, beban barang, beban bunga, beban subsidi, beban hibah, beban bantuan sosial, beban penyusutan aset tetap/amortisasi, beban transfer, dan beban lain-lain. Klasifikasi ekonomi untuk pemerintah daerah terdiri dari beban pegawai, beban barang, beban bunga, beban subsidi, beban hibah, beban bantuan sosial, beban penyusutan aset tetap/amortisasi, beban transfer, dan beban tak terduga (PSAP 12 Paragraf 37 dan 38).

\section{METODE}

Penelitian ini menggunakan metode kualitatif deskriptif dengan memanfaatkan data sekunder yang berasal dari berbagai literatur seperti peraturan, buku-buku, artikel, serta homepage untuk mengakses data dan informasi terkini berkaitan dengan perlakukan akuntansi di bidang akuntansi pemerintah daerah. Penggunaan metode kualitatif deskriptif bertujuan untuk memberikan deskripsi serta mendapatkan gambaran yang jelas yang berguna untuk menjawab rumusan masalah, yaitu mengenai bagaimana perlakukan akuntansi belanja tak terduga pada pemerintah daerah yang saat ini banyak dilakukan oleh pemerintah daerah dalam masa COVID-19. 


\section{HASIL PENELITIAN DAN PEMBAHASAN}

\section{Pengakuan}

Dalam Permendagri No 64 Tahun 2013 Lampiran I disebutkan bahwa Belanja diakui pada saat terjadinya pengeluaran dari Rekening Kas Umum Daerah. Dan khusus pengeluaran melalui bendahara pengeluaran, pengakuan terjadi pada saat pertanggungjawaban atas pengeluaran tersebut disahkan oleh pengguna anggaran. Pengakuan Belanja Tak Terduga akan dilakukan ketika belanja direaliasikan dengan mencatat “Belanja Tak Terduga” di debit, dan mencatat “Estimasi Perubahan SAL" atau “RK-PPKD” di kredit.

Dalam Permendagri Nomor 64 Tahun 2013 Lampiran I juga disebutkan bahwa Beban Tak Terduga akan diakui saat Beban diakui pada saat timbulnya kewajiban, terjadi konsumsi aset, atau terjadinya penurunan manfaat ekonomi atau potensi jasa. Beban belanja tak terduga umumnya muncul dari adanya konsumsi aset yaitu saat pengeluaran kas kepada pihak lain yang tidak didahului timbulnya kewajiban dan/atau kosnumsi aset nonkas dalam kegiatan operasional pemerintah. Tabel 1 menyajikan beberapa kemungkinan pencatat belanja dan beban tak terduga.

Tabel 1. Jurnal Pengakuan Transaksi dari Belanja Tak Terduga

\begin{tabular}{lcc}
\hline & Jurnal Kas & Jurnal Akrual \\
\hline Langsung Digunakan/Dibagikan & Dr Belanja Tak Terduga & Dr Beban Belanja Tak Terduga \\
& Cr Estimasi Perubahan SAL & Cr Kas pada Kas Daerah \\
Melalui penyimpanan di Gudang, & Dr Belanja Tak Terduga & Dr Persediaan \\
lalu dibagikan & Cr Estimasi Perubahan SAL & Cr Kas pada Kas Daerah \\
Membentuk Aset Tetap & Dr Belanja Tak Terduga & Dr Aset Tetap \\
& Cr Estimasi Perubahan SAL & Cr Kas pada Kas Daerah \\
\hline
\end{tabular}

Sumber: diolah, 2020.

\section{Pengukuran}

Dalam Permendagri No. 64 Tahun 2013 Lampiran I disebutkan bahwa akuntansi belanja termasuk Belanja Tak Terduga dilaksanakan berdasarkan azas bruto dan diukur berdasarkan nilai nominal yang dikeluarkan dan tercantum dalam dokumen pengeluaran yang sah.

Sejalan dengan ketentuan dalam Permendagri No. 64 Tahun 2013 Lampiran I, maka pengukuran Beban Tak Terduga dilakukan dengan ketentuan sebagai berikut:

a) Beban dari transaksi non pertukaran diukur sebesar aset yang digunakan atau dikeluarkan yang pada saat perolehan tersebut diukur dengan nilai wajar.

b) Beban dari transaksi pertukaran diukur dengan menggunakan harga sebenarnya (actual price) yang dibayarkan ataupun yang menjadi tagihan sesuai dengan perjanjian yang telah membentuk harga.

Untuk memudahkan pemahaman mengenai bagaimana pengakuan dan pengukuran dari transaksi belanja tak terduga, kita dapat mengikuti ilustasi realisasi belanja tak terduga pada SKPD dan PPKD. Ilustrasi akan diberikan dengan dua alternatif: menggunakan mekanisme Uang Persediaan (UP) dan menggunakan pembayaran Langsung (LS).

\section{Ilustasi Transaksi Realisasi Belanja Tak Terduga pada SKPD dengan Uang Persediaan}

Misalkan suatu SKPD A melakukan belanja untuk pembelian bahan atau kegiatan penanganan COVID-19 dengan menggunakan Uang Persediaan. Dalam pembelanjaan yang dilakukan oleh Bendahara Pengeluaran, atas belanja tersebut dibebankan pada Belanja Tak Terduga. Transaksi yang dilakukan atas UP adalah sebagai berikut. 
1 Maret SKPD A mengajukan Surat Perintah Membayar Uang Persediaan (SPM-UP) sebesar Rp100.000.000,00, dan Surat Perintah Pencairan Dana (SP2D) terbit pada hari tersebut.

4 Maret Bendahara SKPD A membayar tagihan pembelian bahan desinfektan habis pakai senilai Rp25.000.000,00

10 Maret Bendahara SKPD A membayar tagihan pembelian atas Alat Pelindung Diri (APD) sebesar Rp40.000.000,00 yang akan diberikan kepada tenaga kesehatan, namun APD tersebut disimpan terlebih dahulu sebagai persediaan.

17 Maret Bendahara SKPD A membayar tagihan pembelian alat pendeteksi suhu secara otomatis Rp20.000.000,00. Alat tersebut diestimasi berumur 4 tahun dan dapat dikategorikan aset tetap

28 Maret Dilakukan pertanggungjawaban atas belanja dengan menggunakan Uang Persediaan (UP) melalui mekanisme SPM Ganti Uang Persediaan (SPM-GUP) yang revolving. Pada tanggal tersebut terbit SP2D-GUP.

Pada tanggal 1 Maret telah dilakukan pencatatan oleh SKPD A pada jurnal akrual atas kas yang diterima oleh Bendahara Pengeluaran, namun dalam jurnal kas belum dilakukan pencatatan, karena belum terdapat belanja negara. Pada tanggal 4 Maret belum dilakukan pencatatan baik pada jurnal akrual maupun pada jrunal kas karena pada tanggal tersebut belum dilakukan otorisasi oleh Pengguna Anggaran (PA) atau Kuasa Pengguna Anggaran (KPA). Kejadian tersebut sama halnya terjadi atas transaksi pada tanggal 10 Maret dan 17 Maret. Pada tanggal 28 Maret dilakukan pencatatan baik pada jurnal akrual maupun pada jurnal kas karena pada tanggal tersebut telah dilakukan otorisasi oleh Pengguna Anggaran (PA) atau Kuasa Pengguna Anggaran (KPA). Tabel 2 dan Tabel 3 menyajikan jurnal pencatatan SKPD baik untuk jurnal kas maupun jurnal akrual ketika pembayaran dilakukan dengan UP.

Tabel 2. Jurnal Kas dari Sisi SKPD untuk Pembayaran dengan UP

\begin{tabular}{clcc}
\hline Tanggal & \multicolumn{1}{c}{ Uraian } & $\mathrm{Dr}$ & $\mathrm{Cr}$ \\
\hline 1 Maret & (tidak ada pencatatan) & & \\
4 Maret & (tidak ada pencatatan) & & \\
10 Maret & (tidak ada pencatatan) & & \\
17 Maret & (tidak ada pencatatan) & 100.000 .000 & 100.000 .000 \\
28 Maret & Belanja Tak Terduga & & \\
& Estimasi Perubahan SAL & & \\
& (pengesahan belanja tak terduga dengan UP) & & \\
\hline
\end{tabular}

Sumber: diolah, 2020.

Tabel 3. Jurnal Akrual dari Sisi SKPD untuk Pembayaran dengan UP

\begin{tabular}{|c|c|c|c|}
\hline Tanggal & Uraian & $\mathrm{Dr}$ & $\mathrm{Cr}$ \\
\hline \multirow[t]{4}{*}{1 Maret } & Kas di Bendahara Pengeluaran & 100.000 .000 & \\
\hline & RK-PPKD & & 100.000 .000 \\
\hline & (mencatat bertambahnya Kas di Bendahara & & \\
\hline & Pengeluaran setelah UP diterima) & & \\
\hline 4 Maret & (tidak ada pencatatan) & & \\
\hline 10 Maret & (tidak ada pencatatan) & & \\
\hline 17 Maret & (tidak ada pencatatan) & & \\
\hline \multirow[t]{2}{*}{28 Maret } & Beban Tak Terduga & 25.000 .000 & \\
\hline & $\begin{array}{l}\text { Kas di Bendahara Pengeluaran } \\
\text { (pengesahan belanja tak terduga yang habis } \\
\text { pakai) }\end{array}$ & & 25.000 .000 \\
\hline \multirow[t]{2}{*}{28 Maret } & Persediaan & 40.000 .000 & \\
\hline & Kas di Bendahara Pengeluaran & & 40.000 .000 \\
\hline
\end{tabular}




\begin{tabular}{|c|c|c|c|}
\hline Tanggal & Uraian & $\mathrm{Dr}$ & $\mathrm{Cr}$ \\
\hline \multirow{3}{*}{28 Maret } & $\begin{array}{l}\text { (pengesahan belanja tak terduga yang } \\
\text { menghasilkan persediaan) }\end{array}$ & & \\
\hline & Peralatan dan Mesin & 20.000 .000 & \multirow{3}{*}{20.000 .000} \\
\hline & $\begin{array}{l}\text { Kas di Bendahara Pengeluaran } \\
\text { (pengesahan belanja tak terduga yang } \\
\text { menghasilkan aset tetap peralatan dan mesin) }\end{array}$ & & \\
\hline \multirow[t]{3}{*}{28 Maret } & Kas di Bendahara Pengeluaran & 85.000 .000 & \\
\hline & RK-PPKD & & \multirow[t]{2}{*}{85.000 .000} \\
\hline & $\begin{array}{l}\text { (mencatat pengisian kembali UP setelah } \\
\text { pengesahan belanja tak terduga) }\end{array}$ & & \\
\hline
\end{tabular}

Sumber: diolah, 2020.

Ilustrasi pada PPKD atas Belanja Tak Terduga dengan Uang Persediaan (UP). Atas transaksi yang berkaitan dengan belanja pada SKPD A pada ilustrasi sebelumnya, PPKD juga melakukan transaksi yang bersifat resiprokal. Transaksi tersebut hanya terjadi atas transaksi yang bersifat kas, karena PPKD memerankan diri sebagai Bendahara Umum Daerah (BUD).

1 Maret PPKD menerbitkan Surat Perintah Pencairan Dana (SP2D) atas SPMN-UP yang diterbitkan SKPD A sebesar Rp100.000.000,00,

4 Maret PPKD tidak melakukan transaksi

10 Maret PPKD tidak melakukan transaksi

17 Maret PPKD tidak melakukan transaksi

28 Maret PPKD melakukan penerbitan SP2D-GU atas pertanggungjawaban belanja SKPD A dengan menggunakan Uang Persediaan (UP) melalui mekanisme Ganti Uang Persediaan (GUP) yang revolving.

Transaksi pada PPKD dilakukan pencatatan hanya untuk transaksi pada tanggal 1 Maret dan pada tanggal 28 Maret. Kedua transaksi tersebut dicatat karena pada transaksi tersebut, PPKD menerbitkan SP2D sebagai perintah kepada bank operasional yang memegang rekening pemerintah daerah. Tabel 4 dan Tabel 5 menyajikan jurnal pencatatan PPKD baik untuk jurnal kas maupun jurnal akrual ketika pembayaran dilakukan dengan UP.

Tabel 4. Jurnal Kas dari Sisi PPKD untuk Pembayaran dengan UP

\begin{tabular}{|c|c|c|c|}
\hline Tanggal & Uraian & $\mathrm{Dr}$ & $\mathrm{Cr}$ \\
\hline 1 Maret & (tidak ada pencatatan) & & \\
\hline 4 Maret & (tidak ada pencatatan) & & \\
\hline 10 Maret & (tidak ada pencatatan) & & \\
\hline 17 Maret & (tidak ada pencatatan) & & \\
\hline \multirow[t]{2}{*}{28 Maret } & Estimasi Perubahan SAL & 85.000 .000 & \\
\hline & $\begin{array}{l}\text { Kas di Kas Daerah } \\
\text { (pengesahan belanja tak terduga dengan UP) }\end{array}$ & & 85.000 .000 \\
\hline
\end{tabular}

Sumber: diolah, 2020. 
Tabel 5. Jurnal Akrual dari Sisi PPKD untuk Pembayaran dengan UP

\begin{tabular}{|c|c|c|c|}
\hline Tanggal & Uraian & $\mathrm{Dr}$ & $\mathrm{Cr}$ \\
\hline 1 Maret & RK-SKPD & 100.000 .000 & \\
\hline & Kas di Kas Daerah & & 100.000.000 \\
\hline & (mencatat berkurangnya Kas di Kas Daerah) & & \\
\hline 4 Maret & (tidak ada pencatatan) & & \\
\hline 10 Maret & (tidak ada pencatatan) & & \\
\hline 17 Maret & (tidak ada pencatatan) & & \\
\hline \multirow[t]{4}{*}{28 Maret } & RK-SKPD & 85.000 .000 & \\
\hline & Kas di Kas Daerah & & 85.000 .000 \\
\hline & (mencatat pengisian kembali UP setelah & & \\
\hline & pengesahan belanja tak terduga) & & \\
\hline
\end{tabular}

Sumber: diolah, 2020.

\section{Ilustrasi Transaksi Realisasi Belanja Tak Terduga pada SKPD dengan Pembayaran Langsung}

Misalkan suatu SKPD A melakukan belanja untuk pembelian bahan atau kegiatan penanganan COVID-19 dengan menggunakan Pembayaran Langsung. Pembelanjaan tersebut dibebankan pada Belanja Tak Terduga. Transaksi yang dilakukan SKPD A adalah sebagai berikut.

4 April SKPD A menerbitkan Surat Perintah Membayar Langsung (SPM-LS) untuk membayar tagihan pembelian bahan desinfektan habis pakai senilai Rp25.000.000,00; SP2D terbit pada hari yang sama.

10 April SKPD A menerbitkan SPM-LS untuk membayar tagihan pembelian atas Alat Pelindung Diri (APD) sebesar Rp40.000.000,00 yang akan diberikan kepada tenaga kesehatan, namun APD tersebut disimpan terlebih dahulu sebagai persediaan. SP2D atas SPM tersebut pada hari yang sama.

17 April SKPD A menerbitkan SPM-LS untuk membayar tagihan pembelian alat pendeteksi suhu secara otomatis Rp20.000.000,00. Alat tersebut diestimasi berumur 4 tahun dan dapat dikategorikan aset tetap.

Pada transaksi pengeluaran dengan pembayaran secara langsung, pada setiap pembayaran dilakukan pencatatan baik pada jurnal kas maupun pada jurnal akrual. Dengan demikian, maka baik untuk transaksi tanggal 4 April, 10 April, dan 28 April dilakukan pencatatan dengan menggunakan jurnal yang sama. Jurnal kas akan mencatat adanya pengeluaran kas dari Kas di Kas Daerah yaitu adanya pembayaran kepada pihak ketiga atau penyedian barang dan/atau jasa. Sedangkan jurnal akrual akan mencatat terjadinya perubahan pada akun akrual pada neraca SKPD. Tabel 6 dan Tabel 7 menyajikan jurnal pencatatan SKPD baik untuk jurnal kas maupun jurnal akrual ketika pembayaran dilakukan dengan LS.

Tabel 6. Jurnal Kas dari Sisi SKPD untuk Pembayaran secara Langsung (LS)

\begin{tabular}{|c|c|c|c|}
\hline Tanggal & Uraian & $\mathrm{Dr}$ & $\mathrm{Cr}$ \\
\hline 4 April & $\begin{array}{l}\text { Belanja Tak Terduga } \\
\quad \text { Estimasi Perubahan SAL } \\
\text { (mencatat realisasi belanja membentuk beban) }\end{array}$ & 25.000 .000 & 25.000 .000 \\
\hline 10 April & $\begin{array}{l}\text { Belanja Tak Terduga } \\
\quad \text { Estimasi Perubahan SAL } \\
\text { (mencatat realisasi belanja membentuk } \\
\text { persediaan) }\end{array}$ & 40.000 .000 & 40.000 .000 \\
\hline 17 April & $\begin{array}{l}\text { Belanja Tak Terduga } \\
\text { Estimasi Perubahan SAL } \\
\text { (mencatat realisasi belanja membentuk aset } \\
\text { tetap) }\end{array}$ & 20.000 .000 & 20.000 .000 \\
\hline
\end{tabular}

Sumber: diolah, 2020. 
Tabel 7. Jurnal Akrual dari Sisi SKPD untuk Pembayaran secara Langsung (LS)

\begin{tabular}{|c|c|c|c|}
\hline Tanggal & Uraian & $\mathrm{Dr}$ & $\mathrm{Cr}$ \\
\hline 4 April & $\begin{array}{l}\text { Beban Tak Terduga } \\
\text { Kas di Bendahara Pengeluaran } \\
\text { (mencatat beban tak terduga) }\end{array}$ & 25.000 .000 & 25.000 .000 \\
\hline 10 April & $\begin{array}{l}\text { Persediaan } \\
\quad \text { Kas di Bendahara Pengeluaran } \\
\text { (mencatat persediaan) }\end{array}$ & 40.000 .000 & 40.000 .000 \\
\hline 17 April & $\begin{array}{l}\text { Peralatan dan Mesin } \\
\quad \text { Kas di Bendahara Pengeluaran } \\
\text { (mencatat aset tetap-peralatan dan mesin) }\end{array}$ & 20.000 .000 & 20.000 .000 \\
\hline
\end{tabular}

Sumber: diolah, 2020.

Ilustrasi pada PPKD atas Belanja Tak Terduga dengan Pembayaran Langsung (LS). Atas transaksi yang berkaitan dengan belanja pada SKPD A pada ilustrasi sebelumnya, PPKD juga melakukan transaksi yang bersifat resiprokal. Transaksi tersebut hanya terjadi atas transaksi yang berkaitan dengan kas, karena PPKD memerankan diri sebagai Bendahara Umum Daerah (BUD). Akan tetapi, jurnal pada PPKD sama halnya pada SKPD, dilakukan dengan penca

4 April PPKD menerbitkan SP2D Rp25.000.000,00.

10 April PPKD menerbitkan SP2D Rp40.000.000,00.

17 April PPKD menerbitkan SP2D Rp20.000.000,00.

Transaksi pada PPKD dilakukan pencatatan hanya untuk transaksi pada tanggal 4 April, 10 April, dan 17 April. Transaksi-transaksi tersebut dicatat karena PPKD menerbitkan SP2D sebagai perintah kepada bank operasional yang memegang rekening pemerintah daerah. Tabel 8 dan Tabel 9 menyajikan jurnal pencatatan PPKD baik untuk jurnal kas maupun jurnal akrual ketika pembayaran dilakukan dengan LS.

Tabel 8. Jurnal Kas dari Sisi PPKD untuk Pembayaran secara Langsung (LS)

\begin{tabular}{|c|c|c|c|}
\hline Tanggal & Uraian & $\mathrm{Dr}$ & $\mathrm{Cr}$ \\
\hline 4 April & $\begin{array}{l}\text { Estimasi Perubahan SAL } \\
\quad \text { Kas di Kas Daerah } \\
\text { (mencatat realisasi belanja tak terduga yang } \\
\text { membentuk beban) }\end{array}$ & 25.000 .000 & 25.000 .000 \\
\hline 10 April & $\begin{array}{l}\text { Estimasi Perubahan SAL } \\
\quad \text { Kas di Kas Daerah } \\
\text { (mencatat realisasi belanja tak terduga yang } \\
\text { membentuk persediaan) }\end{array}$ & 40.000 .000 & 40.000 .000 \\
\hline 17 April & $\begin{array}{l}\text { Estimasi Perubahan SAL } \\
\quad \text { Kas di Kas Daerah } \\
\text { (mencatat realisasi belanja tak terduga yang } \\
\text { membentuk persediaan) }\end{array}$ & 20.000 .000 & 20.000 .000 \\
\hline
\end{tabular}

Sumber: diolah, 2020. 
Tabel 9. Jurnal Akrual dari Sisi PPKD untuk Pembayaran secara Langsung (LS)

\begin{tabular}{|c|c|c|c|}
\hline Tanggal & Uraian & $\mathrm{Dr}$ & $\mathrm{Cr}$ \\
\hline \multirow[t]{2}{*}{4 April } & RK-SKPD & 25.000 .000 & \\
\hline & $\begin{array}{l}\text { Kas di Kas Daerah } \\
\text { (mencatat berkurangnya Kas di Kas Daerah) }\end{array}$ & & 25.000 .000 \\
\hline \multirow[t]{2}{*}{10 April } & RK-SKPD & 40.000 .000 & \\
\hline & $\begin{array}{l}\text { Kas di Kas Daerah } \\
\text { (mencatat berkurangnya Kas di Kas Daerah) }\end{array}$ & & 40.000 .000 \\
\hline \multirow[t]{2}{*}{17 April } & RK-SKPD & 20.000 .000 & \\
\hline & $\begin{array}{l}\text { Kas di Kas Daerah } \\
\text { (mencatat berkurangnya Kas di Kas Daerah) }\end{array}$ & & 20.000 .000 \\
\hline
\end{tabular}

Sumber: diolah, 2020.

\section{Penyajian di Laporan Keuangan}

Realisasi Belanja Tak Terduga akan membawa dampak penyajian pada beberapa jenis laporan keuangan pemerintah daerah. Jenis laporan tersebut adalah laporan Realisasi Anggaran (LRA), Laporan Operasional (LO), dan Neraca.

Penyajian di Laporan Realisasi Anggaran (LRA). Belanja Tak Terduga merupakan bagian dari belanja operasi, sehingga akan tersaji dalam Laporan Realisasi Anggaran (LRA). Realisasi Belanja Tak Terduga baik dalam bentuk pemberian tunai maupun barang disajikan pada LRA sebesar nilai Belanja Tak Terduga yang direalisasikan.

Penyajian di Laporan Operasional. Beban disajikan dalam Laporan Operasional, dan koreksi atas beban, termasuk penerimaan kembali pembayaran belanja yang membentuk beban yang terjadi pada periode yang sama. Apabila diterima pada periode berikutnya, koreksi atas Beban Belanja Tak Terduga akan dibukukan dalam Pendapatan Lain-lain. Apabila koreksi tersebut mengakibatkan penambahan beban, maka perlu dilakukan pembetulan/pengurangan pada akun ekuitas.

Penyajian di Laporan Arus Kas (LAK). Belanja Tak Terduga akan tersaji dalam LAK pada bagian aktivitas operasi untuk seksi arus kas keluar. Penyajian di LAK dilakukan dengan melakukan komparasi dengan tahun sebelumnya.

Penyajian di Neraca. Belanja Tak Terduga dapat berakibat terhadap penyajian dalam Neraca. Belanja Tak Terduga berbentuk barang dengan umur kurang dari satu tahun akan disajikan sebagai kelompok persediaan di Neraca. Utang Belanja Tak Terduga disajikan dalam kelompok kewajiban atas jumlah belanja bantuan sosial yang belum

\section{SIMPULAN}

Kriteria dalam pengeluaran belanja tak terduga diperlukan untuk mengenali belanja apa saja yang dapat diklasifikasikan sebagai belanja tak terduga. Kriteria belanja yang dapat ditampung dalam belanja tak terduga pada suatu pemerintah daerah adalah digunakan untuk kegiatan yang sifatnya tidak biasa dan tidak diharapkan berulang seperti penanggulangan bencana alam, bencana sosial, dan pengeluaran tidak terduga lainnya yang sangat diperlukan dalam rangka penyelenggaraan kewenangan pemerintah daerah.

Pencatatan akuntansi dari Belanja Tak Terduga berbeda antara belanja tak terduga yang langsung menjadi beban, mengakibatkan timbulnya persediaan atau mengakibatkan timbulnya aset tetap. Pencatatan Belanja tak terduga akan melibatkan pencatatan pada SKPD dan PPKD.

Belanja Tak Terduga akan dapat berpengaruh pada dalam penyajian laporan keuangan pada Laporan Realisasi Anggaran (LRA), Laporan Operasional (LO), Laporan Arus Kas (LAK) dan Neraca. Penelitian 
selanjutnya perlu mendalami mengenai perlakukan penyesuaian APBD dan/atau Dokumen Pelaksanaan Anggaran (DPA) apabila diketemukan kondisi bahwa anggaran belanja tak terduga belum tersedia mencukupi.

\section{REFERENSI}

DJPK. (2016). Modul Peningkatan Kapasitas Penegloalan Keuangan Daerah - Akuntansi Keuangan Pemerintah Daerah. Jakarta: DJPK.

DJPK. (2020). Belanja Tak Terduga. Available at:

http://www.djpk.kemenkeu.go.id/?ufaq=apakah-yang-dimaksud-dengan-belanja-tidak-terduga. 19 Juni 2020.

Erlina, at all. (2015). Akuntansi Keuangan Daerah. Jakarta Selatan: Salemba Empat.

instruksi Nomor 4 Tahun 2020 tentang Refocussing Kegiatan, Realokasi Anggaran, serta Pengadaan Barang dan Jasa Dalam Rangka Percepatan Penanganan COVID-19.

Keputusan Bersama Menteri Dalam Negeri dan Menteri Keuangan No. 119/2813/SJ dan No. 177/KMK.07/2020 tentang Percepatan Penyesuaian Anggaran Pendapatan dan Belanja Daerah Tahun 2020 dalam Rangka Penanganan COVID-19 serta Pengamanan Daya Beli Masyarakat dan Perekonomian Nasional.

KSAP. (2006). Buletin Teknis Standar Akuntansi Pemerintahan 04 tentang Penyajian dan Pengungkapan Belanja Pemerintah. Jakarta: KSAP RI.

Mardiasmo. (2009). Akuntansi Sektor Publik. Yogyakarta: ANDI.

Medina. (2014). Akrual itu Mudah. Depok: Medina Multi Mitra.

Mulyana, B. (2014). Akuntansi Keuangan Daerah Berbasis Akrual. Jakarta: PKN STAN Press.

Peraturan Menteri Dalam Negeri Republik Indonesia Nomor 90 Tahun 2019 tentang Klasifikasi, Kodefikasi, dan Nomenklatur Perencanaan Pembangunan dan Keuangan Daerah lampiran.

Peraturan Menteri Dalam Negeri Nomor 64 Tahun 2013 tentang Penerapan Standar Akuntansi Pemerintahan Berbasis Akrual pada Pemerintah Daerah.

Peraturan Pemerintah Republik Indonesia Nomor 12 Tahun 2019 tentang Pengelolaan Keuangan Daerah pasal

Pernyataan Standar Akuntansi Pemerintah Nomor 2 tentang Laporan Realisasi Anggaran Berbasis Kas. Jakarta: KSAP. 